\title{
Snowshoe Hare Optimal Foraging and Its Implications for Population Dynamics
}

\author{
GARY E. BELOVSKY \\ University of Michigan, School of Natural Resources, Ann Arbor, Michigan 48109 \\ Received November 15, 1982
}

\begin{abstract}
The results of an optimal foraging model using linear programming with constraints for feeding time, digestive capacity, sodium requirements, and energy requirements indicate that snowshoe hare (Lepus americanus) may forage as energy maximizers. The solution provides the quantities of major food classes (leaves, herbs, fungus, twigs) included in the diet. The species composition of each diet class also is determined using a simultaneous search model based upon the probability of encounter, the probability of sufficient item size, and the probability of sufficient quality. The results also indicate that hare life history parameters (weaning size, size at first reproduction, average adult size) and potential demographic changes in hare populations may be controlled by foraging considerations.
\end{abstract}

Snowshoe hare (Lepus americanus) populations are notable for their 10year population cycles of high amplitude (Keith, 1963; Keith and Windberg, 1978; Finerty, 1980). Recently, Pease et al. (1979) demonstrated that food shortages likely elicit observed snowshoe hare cycles. In light of these findings, the foraging strategies (Schoener, 1971; Pyke et al., 1977) of hare in a cyclic population were examined to ascertain (1) what goals and constraints might influence hare foraging, and (2) how sensitive hare foraging constraints are to variations in quantity and quality of food plants which might lead to changes in survivorship and reproduction.

The foraging model used in this paper was presented by Belovsky (1978) for moose (Alces alces). This model employs the optimization technique of linear programming to solve for two alternative goals: energy maximization or time minimization (Schoener, 1971). Energy maximization provides the forager with the greatest amount of energy for maintenance, growth, reproduction, and survival, while time minimization leads to sufficient energy for maintenance in the least foraging time, presumably reducing the forager's exposure to deleterious factors in the environment (e.g., predators, excessive heat losses). Four constraint equations are employed in the model: (1) digestive organ capacity, (2) maximum daily feeding time, (3) daily sodium requirement, and (4) daily energy requirement. 
Using the linear-programming foraging model, snowshoe hare are shown to seek a goal of energy maximization in their feeding and to select food plants based upon a minimum quality and quantity necessary to provide maintenance and reproductive energy requirements. Also, hare are found to have life history parameters (body sizes at weaning and first reproduction) which can be explained from a strategy of energy maximization. Finally, sensitivity analysis of the model indicates that hare reproduction, not mortality, may be most sensitive to changes in food characteristics, especially sodium content and digestibility.

\section{STUdy AREA}

Hare were studied in an upland forest at Isle Royale National Park, Michigan, which has been described in detail elsewhere (Belovsky and Jordan, 1978). Hare are known to cycle with a 10-year frequency at Isle Royale (Mech, 1966; Johnson, 1970). The study was carried out during the summers (June-September) of 1973 and 1974, and one winter, February 1974 , a period of increasing hare numbers.

\section{METHODS}

\section{Construction of the Linear-Programming Model.}

Data had to be collected for each of the model's constraint equations.

1. Digestive Organ Capacity-Food Bulk. The capacity of a snowshoe hare to process food is probably set by the size of its stomach and caecum/upper colon, the sites of plant tissue breakdown in lagomorphs (McBee, 1971). This capacity was measured by collecting hare of different body weights that had recently completed feeding, immediately removing their stomachs and caeca/upper colons, and weighing the wet contents. It was found that a hare's digestive organ contents scaled with body weight $\left(r^{2}=0.99\right.$, contents (g-wet) $=0.09 W_{g}^{1.03 \pm 0.2}, n=6, p<0.01$ ).

In addition to measuring the hare's ability to process food, the rate at which the food turns over in these organs must be known. This was accomplished by chopping up food and cotton thread as a low digestibility marker, allowing captive hare to eat this mixture, collecting their feces every $\frac{1}{2} \mathrm{hr}$ and then picking through the feces to find thread fragments. The sum of fragments or weight of thread recovered over time since feeding could then be used to estimate mean retention time: the average time required for a thread fragment to pass. The chopped vegetation fed to the hare in these 
experiments was approximately $1.5 \times 0.5 \mathrm{~cm}$, a size small enough to mix with the thread $(0.5-\mathrm{cm}$ lengths) but large enough to require the hare to masticate as much as a bite from a full food item. Passage rate experiments were performed for both green foods (leaves of forbs and deciduous shrubs) and winter twigs (deciduous and conifer), providing respective mean retention times of $3.5 \mathrm{hr}(\mathrm{SE}=0.15, n=3)$ and $8.0 \mathrm{hr}(\mathrm{SE}=0.91, n=3)$.

Using the plant bulk values (wet wt/dry wt) from Isle Royale (Belovsky and Jordan, 1978; Belovsky, 1981a) and a value of 10 for fungus, which I measured, the hare's daily digestive capacity could be written as

$$
\left(24 \mathrm{hr} \mathrm{d}^{-1} / 3.5 \mathrm{hr}\right)\left(0.096 W^{1.03} \text { g-wet }\right) \geqslant 10 f+4.4 h+4.0 l
$$

in summer or

$$
\left(24 \mathrm{hr} \mathrm{d}^{-1} / 8.0 \mathrm{hr}\right)\left(0.096 \mathrm{~W}^{1.03} \mathrm{~g} \text {-wet }\right) \geqslant 2 d+2.5 \mathrm{c}
$$

in winter, where $f$ is g-dry wt fungus, $h$ is forbs, $l$ is leaves of deciduous shrubs, $d$ is deciduous twigs, and $c$ is conifer twigs.

2. Feeding Time-Cropping Rates. The maximum daily feeding time available for hare was found using the optimum feeding time model developed by Belovsky (1981b). This model determines the maximum time an animal has available to feed each day based upon its thermal physiology (Newtonian heat flow model: Porter and Gates, 1969; Gates, 1980) and whether or not the digestive organ has unfilled capacity to hold food, using the optimization technique of dynamic programming to predict where an animal should be (habitat use) and what it should do (behavior) at a given time of day. Three habitat types were considered: open, deciduous, and coniferous forests. Open forest is less than $20 \%$ canopy covered. The deciduous and coniferous forests are covered $20 \%$ or more by canopy with the deciduous composed of $50 \%$ or more deciduous canopy, and the coniferous forest composed of more than $50 \%$ coniferous canopy. The goal of maximum daily feeding time is achieved by satisfying a series of constraints (Belovsky, 1981b).

(a) The animal's body temperature cannot exceed a maximum or fall below a minimum which provides a "margin for error" from thermal lethality. This body temperature range is measured from animals given an experimental "free choice" of thermal environments. Using captive hare in a pen, where they could rest in a box or feed in the open, their rectal temperatures varied over $1.2^{\circ} \mathrm{C}\left(38-39.2^{\circ} \mathrm{C}\right.$ in summer $)$.

(b) The animal's change in body temperature over $24 \mathrm{hr}$ must be zero. This permits the animal to repeat its selection of habitats and behaviors without violating the above constraint (a) in some future period.

(c) If the animal has a choice of when to feed, it will feed at the times 
and in the habitats when the energetic costs of thermal regulation are lowest. This provides the animal with the greatest net energy intake (food energy ingested less cost of acquisition). For showshoe hare, Hart et al. (1965) indicate that metabolism increases with a slope of 0.76 for deviations of environmental temperature below thermoneutrality, and increases with a slope of 1.5 for deviations above thermoneutrality.

(d) The animal cannot feed if its digestive organ is full and cannot resume feeding until some capacity becomes available again. This constraint, therefore, is linked to the digestive capacity-food bulk constraint presented above.

The thermal environment data used in the model for Isle Royale in summer is from Belovsky (1981b) and the thermal parameters for a hare were measured using captive hare (surface temperature, surface area, respiration rate). The thermal parameters and the model for maximum daily feeding time appear in the Appendix.

The solution to the model for maximum daily feeding time indicates that a snowshoe hare should have $8.7 \mathrm{hr} /$ day in summer for feeding. Observation of captive snowshoe hare feeding in pens $(1.5 \times 1 \times 0.5 \mathrm{~m})$ indicated that they were active for $8.4 \mathrm{hr} / \mathrm{day}(\mathrm{SE}=0.7, n=8)$, suggesting that foraging time may agree with the thermal model's predictions (Fig. 1). The necessary thermal environment and physiological parameters needed to solve the feeding time model were not collected for winter. Mech and Tester (1965), however, found that hare in Minnesota during January are active $13.5 \mathrm{hr} /$ day.

Hare cropping rates for different types of plants were measured by following feeding individuals in the wild at distances between 2 and $15 \mathrm{~m}$. At these distances, the time required to consume 10 herbaceous plants, leaves, twigs, or mushrooms could be determined using $7 \times 35$ binoculars and a stopwatch (Table I). The individuals followed had been acclimated to the observer over a period of time prior to data collection, so that they no longer appeared to be troubled by the observer's presence. The mass of food ingested was determined by multiplying the average item weight (i.e., leaf, mushroom, herbaceous plant, or twig) by the observed cropping rate. Maximum cropping rates for each food type were measured in the same manner except penned hare were observed with food available ad libitum. In addition, observation of wild hare feeding was used to ascertain what fraction of activity time the hare actually spent cropping food (active time less time spent moving to feeding sites from resting sites, time spent moving between feeding sites, and times spent simply chewing or standing). This was found to be $26 \%(\mathrm{SE}=4.7, n=9)$ in both summer and winter, and reflects foraging behaviors not tied directly to the acquisition of the different food types. 

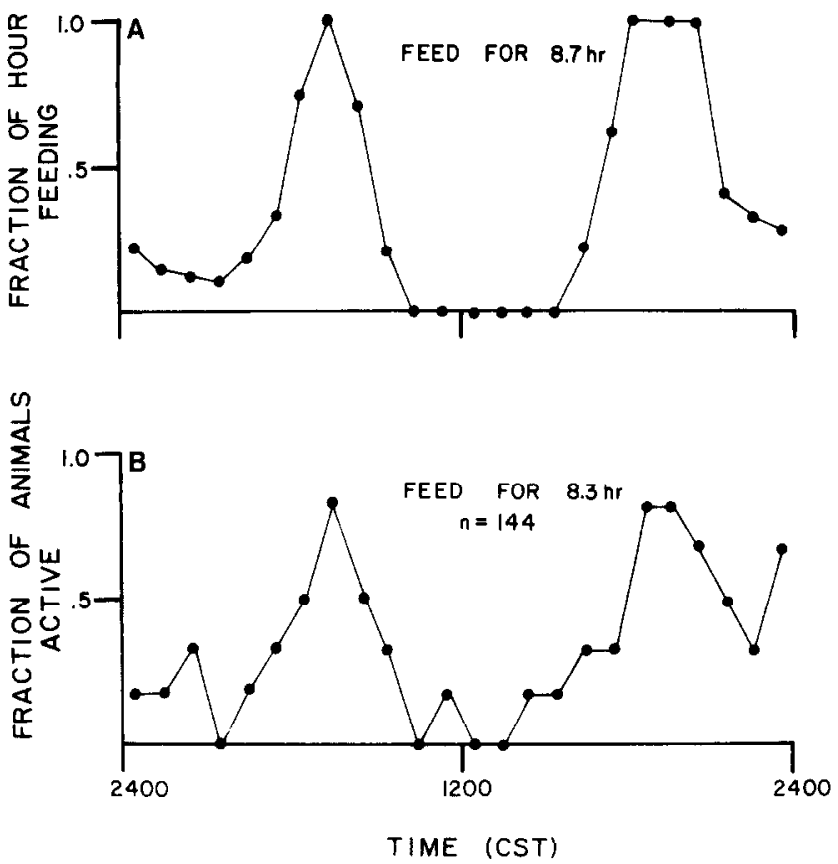

FIG. 1. (A) Predicted fraction of an hour spent foraging by snowshoe hare in summer based upon their thermal physiology plotted for each hour of the day. (B) Observed fraction of each hour spent foraging plotted for each hour of a summer day.

TABLE I

Snowshoe Hare Cropping Rate Parameters and Their Standard, Deviations, Where Available, for Different Food Plant Types

\begin{tabular}{lcrccc}
\hline & $\min / \mathrm{g}$ & $n$ & $(\mathrm{~min})$ & Items/min & $\begin{array}{c}\text { Maximum } \\
\text { items/min }\end{array}$ \\
\hline Leaves & $0.26 \pm 0.16$ & 23 & 12 & 19.23 & 28.46 \\
Herbs & $0.49 \pm 0.20$ & 38 & 156 & 2.43 & 10.3 \\
Fungus & 2.0 & 2 & 40 & - & - \\
Twigs & $0.8 \pm 0.49$ & 20 & 48 & 4.17 & 8.3 \\
\hline
\end{tabular}


With the above feeding parameters, the foraging time-cropping rate constraints on diet can be written as

$$
\left(8.7 \mathrm{hrd}^{-1}\right)\left(60 \operatorname{minh}^{-1}\right)(0.26) \geqslant 2 f+0.49 h+0.26 l
$$

for summer, and

$$
\left(13.0 \mathrm{hr} \mathrm{d}^{-1}\right)\left(60 \mathrm{~min} \mathrm{hr}^{-1}\right)(0.26) \geqslant 0.8 d+0.8 c,
$$

for winter.

3. Sodium Requirement-Food Content. $\mathrm{Na}^{+}$is thought to be a potentially sought-after nutrient by hare at Isle Royale because it is rare in abundance relative to animal needs (Botkin et al., 1973; Jordan et al., 1973) and it influences moose foraging at Isle Royale (Belovsky, 1978; Belovsky and Jordan, 1981; Belovsky, 1981a). A snowshoe hare's $\mathrm{Na}^{+}$requirements were determined using the "balance sheet" approach presented by Belovsky and Jordan (1981) for moose. This requires the measurement of growth, reproduction, and loss of material (urine, feces, etc.) and $\mathrm{Na}$ ' content of each. This was done using captive snowshoe hare in this study and data reported by others on captive hare (Bookhout, 1965; Holter et al., 1974); while $\mathrm{Na}^{+}$content was determined using atomic absorption spectrophotometry or data from others (Smith et al., 1978 for $L$. americanus; Scoggins et al., 1970 for Oryctolagus cuniculus). The $\mathrm{Na}^{+}$data (Table II) were used to compute the amount of $\mathrm{Na}^{+}$adult male and female hare (Table III) needed to ingest if they were to remain in $\mathrm{Na}^{+}$equilibrium over a year.

The sodium content of Isle Royale leaves and twigs is presented by Belovsky and Jordan (1981); the values for herbs average $50 \mathrm{ppm}$ (Likens and Bormann, 1970) while those for fungus are approximately $1000 \mathrm{ppm}$ (H. P. Weeks, pers. comm.). With the $\mathrm{Na}^{+}$food values and $\mathrm{Na}^{+}$requirements, the $\mathrm{Na}^{+}$diet constraints can be constructed. To make the $\mathrm{Na}^{+}$constraints weight-dependent, it was assumed that $\mathrm{Na}^{+}$requirements are linearly related to body mass (Church, 1971) and there is a fixed $\mathrm{Na}^{+}$requirement for females to produce young $(0.043 \mathrm{~g})$, such that in summer ( 120 days of green vegetation)

$$
0.002 W_{\mathrm{kg}} \leqslant 1 \times 10^{-3} f+5 \times 10^{-5} h+1 \times 10^{-5} l,
$$

for a nongrowing male or nonreproductive female in summer, and

$$
0.002 W_{\mathrm{kg}}+0.043 \leqslant 1 \times 10^{-3} f+5 \times 10^{-5} h+1 \times 10^{-5} l,
$$


TABLE II

Parameters Necessary to Compute a Snowshoe Hare's Sodium Budget, along with Their Standard Deviations and Sample Sizes if the Data Are from This Study; Otherwise, the Literature Source Is Given. The Hare Is Assumed to Weigh $1500 \mathrm{~g}$.

\begin{tabular}{|c|c|c|}
\hline & & $n$ \\
\hline \multicolumn{3}{|l|}{ Excretion } \\
\hline \multicolumn{3}{|l|}{ Feces } \\
\hline Summer & $20.8 \mathrm{~g}$ dry $/$ day \pm 17.7 & 30 \\
\hline Winter & $106.5 \mathrm{~g}$ dry $/$ day \pm 111.5 & 5 \\
\hline $\mathrm{Na}^{+}$content & $14.9 \mathrm{ppm} \pm 9.03$ & 5; and Smith et al., 1978 \\
\hline \multicolumn{3}{|l|}{ Urine } \\
\hline Summer & $40.7 \mathrm{ml} / \mathrm{day}+21.3$ & 13 \\
\hline Winter & $10.2 \mathrm{ml} / \mathrm{day} \pm 5.0$ & 3 \\
\hline $\mathrm{Na}^{+}$content & $58.2 \mathrm{ppm} \pm 63.5$ & $\begin{array}{l}\text { Scoggins et al., } 1970 \\
\quad \text { Smith et al., } 1978\end{array}$ \\
\hline \multicolumn{3}{|l|}{ Reproduction } \\
\hline \multicolumn{3}{|l|}{ Fetal } \\
\hline Young & 8.7 young $/ \mathrm{yr} \pm 2.5$ & Bittner and Rongstad, 1982 \\
\hline Weight & $65 \mathrm{~g} /$ fetus & Bookhout, 1965 \\
\hline Amniotic fluid & $26 \mathrm{~g} /$ litter & Austin and Short, 1972 \\
\hline $\mathrm{Na}^{+}$content & $1000 \mathrm{ppm}$ & Belovsky and Jordan, 1981 \\
\hline \multicolumn{3}{|l|}{ Lactation } \\
\hline Milk production & $135 \mathrm{~g} /$ day & Cook, 1972 \\
\hline Duration/litter & 17 days & Aldous, 1937 \\
\hline Litters/yr & $2.5 \pm 0.6$ & Bittner and Rongstad, 1982 \\
\hline $\mathrm{Na}^{+}$content & $\sim 800 \mathrm{ppm}$ & $\begin{array}{l}\text { National Research } \\
\text { Council, 1966, for domestic } \\
\text { rabbit }\end{array}$ \\
\hline \multicolumn{3}{|l|}{ Body Growth } \\
\hline Growth & $800 \mathrm{~g}$ & Cook, 1972 \\
\hline $\mathrm{Na}^{+}$content & $1000 \mathrm{ppm}$ & Belovsky and Jordan, 1978 \\
\hline
\end{tabular}

for reproductive females. Growth would increase the scaling factor from 0.002 to 0.007 . For winter (twig diet, 240 days), the $\mathrm{Na}^{+}$diet constraint is

$$
0.0015 W_{\mathrm{kg}} \mathrm{Na}^{+} \mathrm{d}^{-1} \leqslant 7 \times 10^{-6} d+7 \times 10^{-6} c .
$$

The multiple equations for summer arise because reproduction takes place at this time.

4. Energy Requirements-Food Content. The energy metabolism of snowshoe hare was assumed to be proportional to $W_{\mathrm{kg}}^{0.75}$ (Kleiber, 1961; Hemmingsen, 1960). Hart et al. (1965) found hare to average daily $230.8 \mathrm{kcal} / \mathrm{kg}^{0.75}$ in winter and $254.3 \mathrm{kcal} / \mathrm{kg}^{0.75}$ in summer. Knowing the proportion of hare that are reproductive females in summer for a Michigan population (0.26: Bookhout, 1965), their daily metabolism can be estimated 


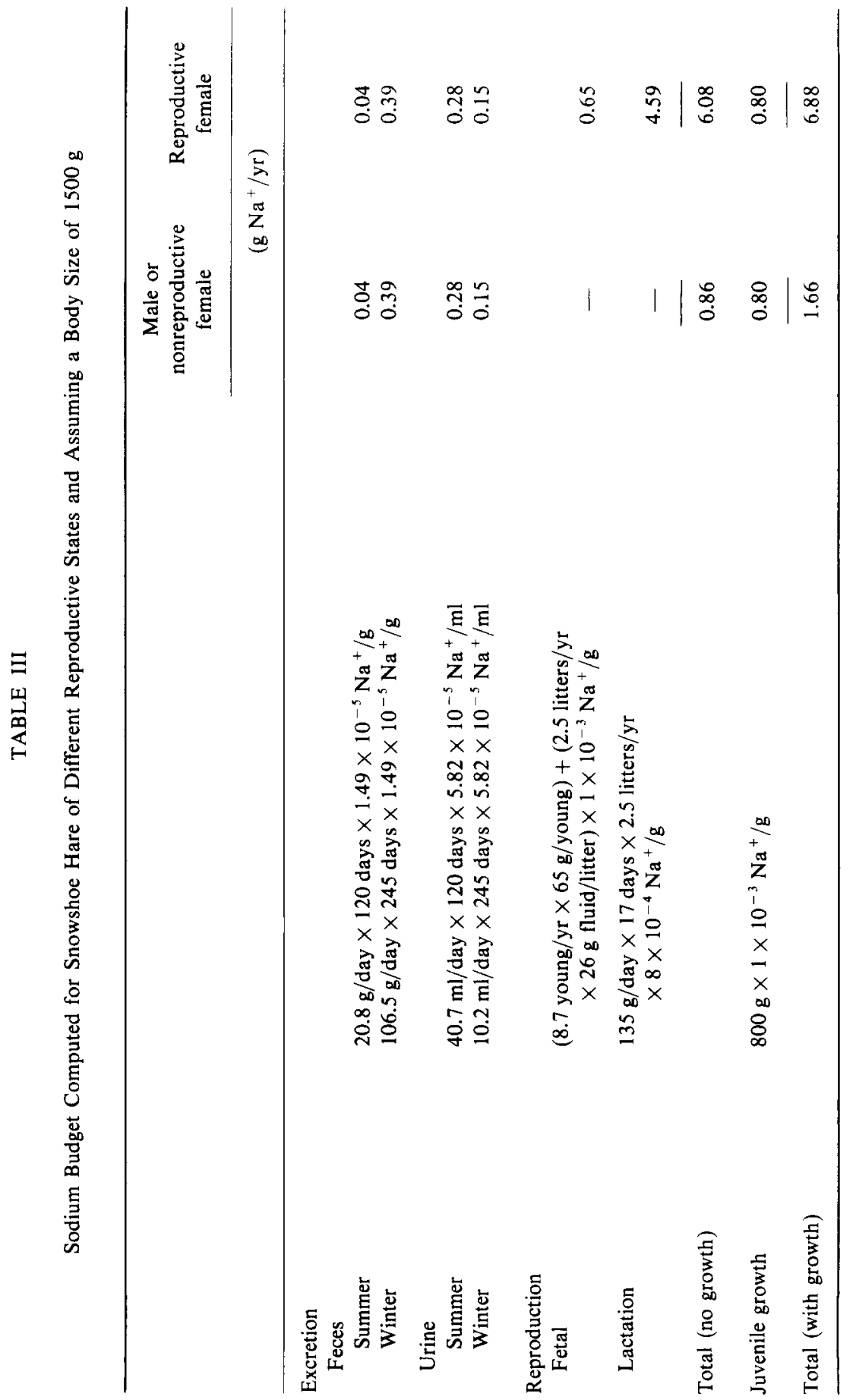


to be $321.2 \mathrm{kcal} / \mathrm{kg}^{0.75}$, assuming males and barren females have a metabolism equivalent to the winter value.

The energy content of foods is $4.2 \mathrm{kcal} \mathrm{g}^{-1}$ dry wt for leaves, $4.8 \mathrm{kcal} \mathrm{g}^{-1}$ dry wt for herbs, $4.2 \mathrm{kcal} \mathrm{g}^{-1}$ dry wt for twigs (Belovsky, 1981a) and $4.0 \mathrm{kcal} \mathrm{g}^{-1} \mathrm{dry}$ wt for fungus (Larcher, 1975). The dry matter digestibilities of different food plants (1-dry wt of feces/dry wt of food intake) was computed using captive hare. Table IV contains the digestibility measurements from this study, as well as from other studies. The digestibility values for each food type are computed as the average of all values available, except for fungus which was assumed to equal the herb value. This provides a conservative value (underestimate) since hare should choose plants of higher digestibility; however, relative values between food classes are most important for the model's solution. Also, the energetic cost of food acquisition is small for hare, less than $0.01 \mathrm{kcal} / \mathrm{g}$ dry wt, since hare travel

\section{TABLE IV}

Dry Matter Digestibility of Different Foods by Snowshoe Hare and the Standard Deviations and Sample Sizes for Measurements from This Study

\begin{tabular}{|c|c|c|c|}
\hline & $\%$ Digestion & $n$ & $\begin{array}{l}\% \text { Mineral }+ \\
\text { protein content }\end{array}$ \\
\hline \multicolumn{4}{|l|}{ Deciduous leaves } \\
\hline Sorbus americana* & 75.0 & 1 & $27.9^{d}$ \\
\hline Rubus parviflorus* & 10.0 & 2 & $25.1^{d}$ \\
\hline \multicolumn{4}{|l|}{ Herbs } \\
\hline Dryopteris spinulosa* & 83.0 & 2 & $22.6^{\circ}$ \\
\hline Streptipus roseus* & $88.0 \pm 4.5$ & 5 & $23.6^{c}$ \\
\hline A ralia nudicaulis* & 0 & 1 & $20.8^{c}$ \\
\hline Clintonia borealis & 28.0 & 1 & $27.2^{c}$ \\
\hline Equisetum sp. & 56.0 & 1 & - \\
\hline Pellets & $54.0 \pm 6.7$ & 3 & 27.3 \\
\hline \multicolumn{4}{|l|}{ Twigs } \\
\hline Thuja occidentalis* & $35.0^{a}$ & & $13.9^{d}$ \\
\hline Acer rubrum* ${ }^{*}$ & $23.0^{a}$ & & $8.2^{d}$ \\
\hline Populus tremuloides* & $43.0^{a}$ & & $12.7^{d}$ \\
\hline Thuja occidentalis* & $52.0^{b}$ & & $15.6^{d}$ \\
\hline Acer rubrum* ${ }^{*}$ & $25.6^{b}$ & & $11.6^{d}$ \\
\hline \multicolumn{4}{|c|}{$\begin{array}{l}{ }^{a} \text { Walski and Mautz (1977). } \\
{ }^{b} \text { Mautz et al. (1976) values were not used to compute mean food-type digestion because } \\
\text { hare were not checked for weight changes; also, the hare were trapped and tested during } \\
\text { summer. Furthermore, the nutrient content of Thuja used was far larger than the Isle Royale } \\
\text { average (Belovsky, 1981a). } \\
{ }^{c} \text { Likens and Bormann (1970). } \\
{ }^{d} \text { Belovsky (1981a). } \\
\text { * Preferred or indifferent. }\end{array}$} \\
\hline
\end{tabular}


on average $2.05 \mathrm{~m}$ to crop $1 \mathrm{~g}$ dry wt of food $(\mathrm{SE}=0.83, n=9)$ and it costs approximately $4.9 \times 10^{-3} \mathrm{kcal} / \mathrm{m}$ (Taylor, $1973: 1.0 \mathrm{~kg}$ hare); therefore, these costs were ignored. The energy requirement constraints can be written as

$$
230.8 W_{\mathrm{kg}}^{0.75} \leqslant 2.02 f+2.44 h+1.80 l
$$

for males and barren females in summer,

$$
321.2 W_{\mathrm{kg}}^{0.75} \leqslant 2.02 f+2.44 h+1.80 l
$$

for reproductive females in summer, and

$$
230.8 W_{\mathrm{kg}}^{0.75} \leqslant 1.39 d+1.47 c
$$

for winter.

Other Feeding Data. Observed hare diets are required to compare with the diets predicted by the linear-programming model (Belovsky, 1978) and with data on characteristics of plants selected by hare to determine whether hare select food plant species based upon minimum quantity and quality values (Belovsky, 1981a).

(a) Observed diet. The summer and winter diets of hare were measured in the same manner as reported for moose (Belovsky and Jordan, 1978; Belovsky, 1981a). Ten 2-m-radius plots were established at 100-m intervals along randomly placed transects. During summer, the number of leaves removed by hare from shrubs with foliage within $1.0 \mathrm{~m}$ of the ground (the height up to which hare were observed to feed) and herbaceous plants or fungus eaten by hare were counted on the plots. Hare consumption could be separated from moose and insect herbivory, the only other upland herbivore species, because hare cut the vegetation with a neat $45^{\circ}$ angle using their incissors. A total of 40 plots were counted in summer for leaves, herbs, and fungus.

The same inventorying of plots was done at the end of winter just before emergence of leaves in spring to count twigs removed by hare. By counting twigs early, before sap rise, the twigs eaten in the current winter could be distinguished from past years' consumption: white cut versus a darkened weathered cut. Again hare removals could be separated from those by other herbivores by the $45^{\circ}$ angle cut. Twigs were examined up to $2.5 \mathrm{~m}$, the height to which hare were observed to feed by standing upon snow drifts. Forty plots were inventoried.

The abundances of each food type are presented elsewhere (Belovsky and Jordan, 1978). For the purposes of this study only plant abundances within a hare's feeding height are reported. Table $V$ contains the observed summer hare diet and food availabilities, and Table VI contains the winter diet and 


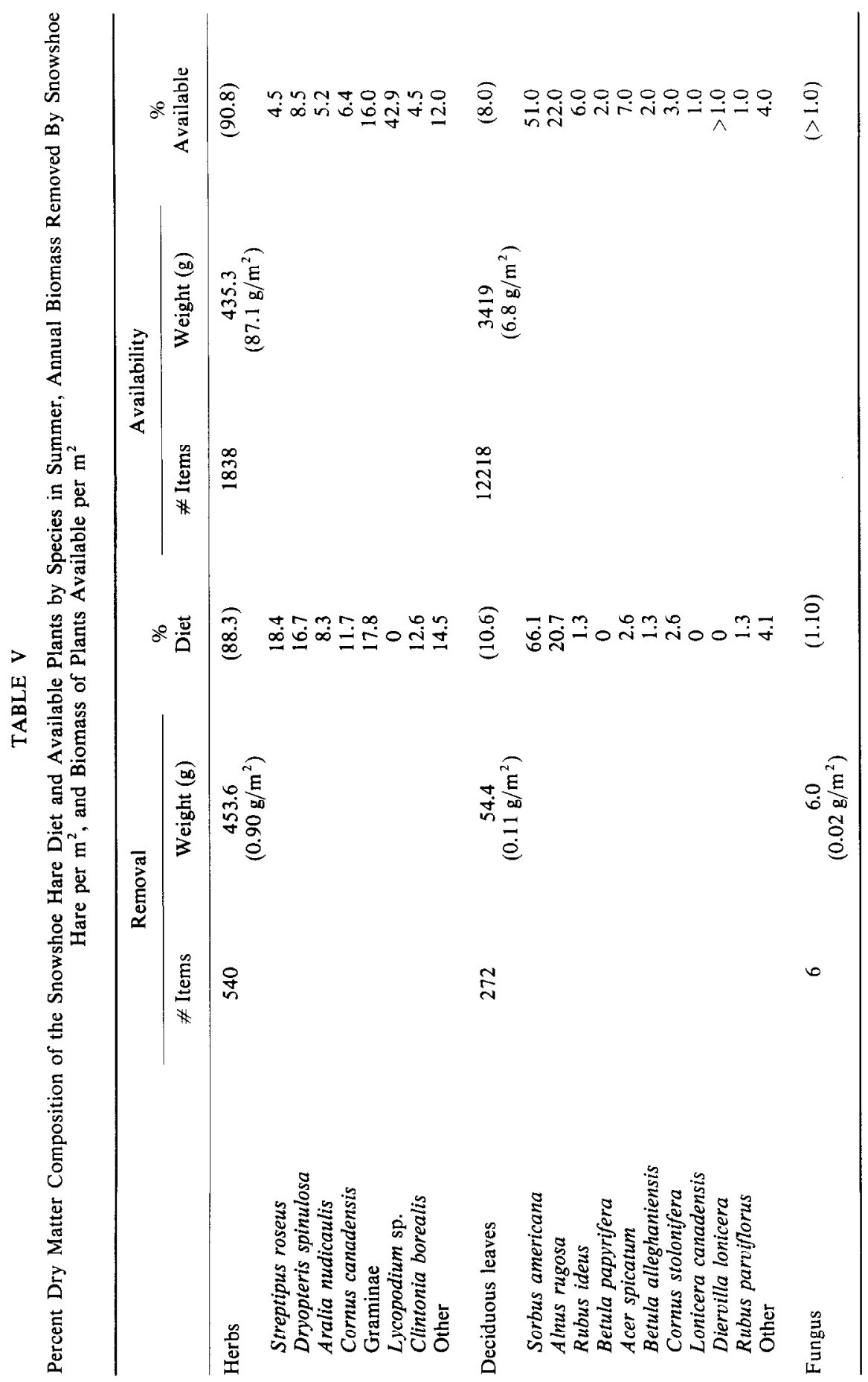




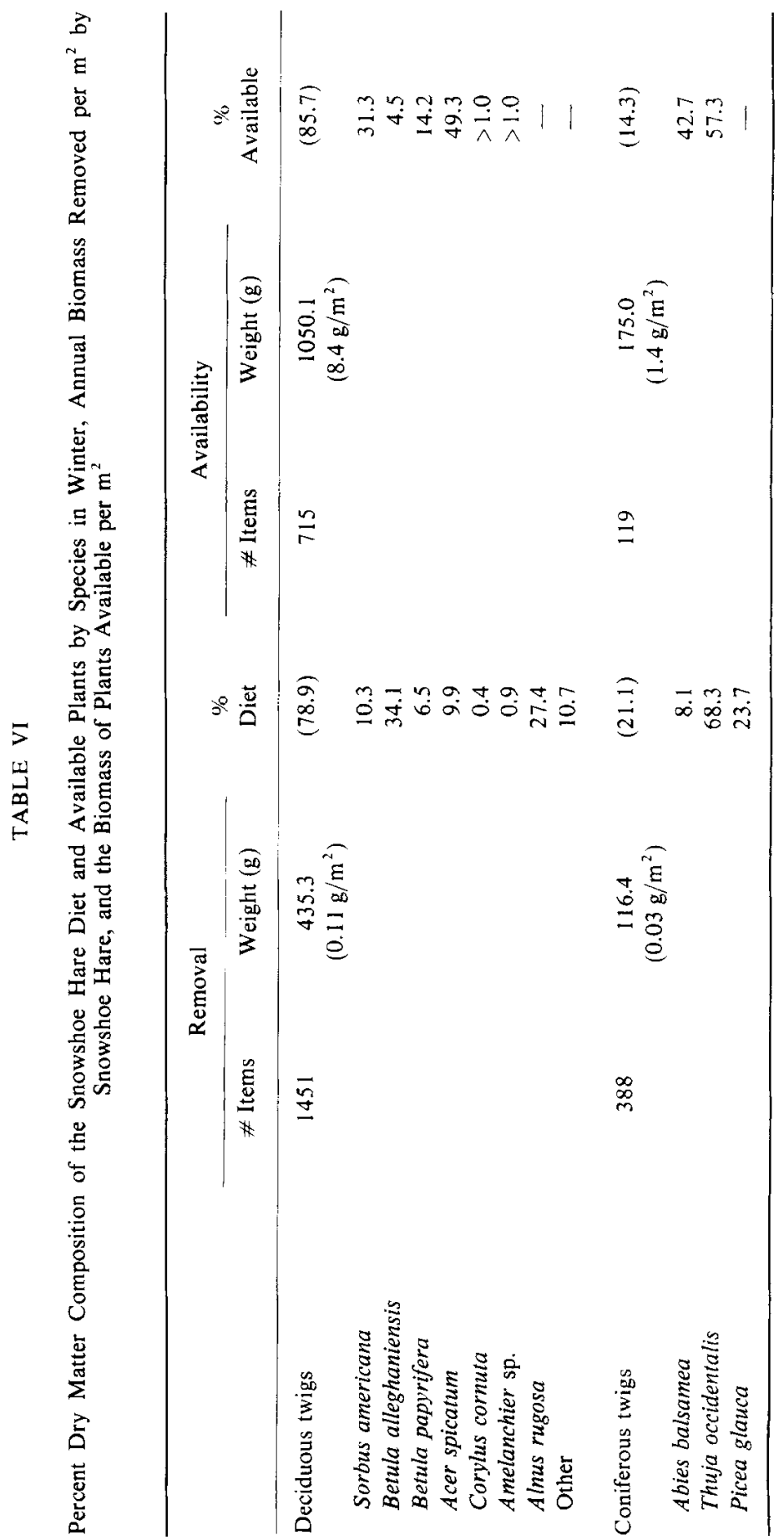


TABLE VII

Mineral plus Protein and Item Size Values for Herbaceous Plants Available to Snowshoe Hare, Standard Deviations, and Item Size Sample Number

\begin{tabular}{lccc}
\hline Species & \% Mineral + protein $^{a}$ & Item size & $n$ \\
\hline Streptipus roseus & $23.6 \pm 1.2$ & $0.85 \pm 0.23$ & 15 \\
Dryopteris spinulosa & $22.6 \pm 1.6$ & $1.18 \pm 0.41$ & 25 \\
Aralia nudicaulis & $20.8 \pm 2.4$ & $1.68 \pm 0.59$ & 25 \\
Lycopodium sp. & $16.5 \pm 0.6$ & $0.87 \pm 0.21$ & 15 \\
Clintonia borealis & $27.2 \pm 3.2$ & $0.80 \pm 0.15$ & 15 \\
Cornus canadensis & - & $0.17 \pm 0.06$ & 25 \\
Graminae & - & $0.06+0.02$ & 25 \\
Aster macrophylla & - & $0.52 \pm 0.09$ & 25 \\
\hline
\end{tabular}

${ }^{a}$ Likens and Bormann (1970).

food availabilities. Both summer and winter hare diets are significantly different from the food available in the environment.

(b) Characteristics of consumed plants. The nutrient content of plants consumed by hare has been presented for leaves and twigs in Belovsky (1981a), while those for herbaceous plants (Table VII) were taken from Likens and Bormann's (1970) study at Hubbard Brook, New Hampshire. The size of food items consumed by hare was determined by measuring the petiole, stem, or remainder of a leaf, plant, or twig with calipers. The observer then collected a leaf, plant, or twig of the same species and diameter for later drying and weighing. These samples provide the mean item sizes sclected by harc. The means of the smallest and largest $10 \%$ of items were used as measures of maximum and minimum sizes selected (Table VIII).

TABLE VIII

Mean, Minimum, and Maximum Item Sizes Selected by Snowshoe Hare, along with Standard Deviations and Sample Sizes Where Applicable

\begin{tabular}{lcccc}
\hline & & \multicolumn{3}{c}{ Item size } \\
\cline { 3 - 5 } Item & $N$ & Mean & Minimum & Maximum \\
\hline Deciduous leaves & 290 & $0.20 \mathrm{~g} \pm 0.12$ & 0.09 & - \\
Herbs & 150 & $0.84 \mathrm{~g} \pm 0.49$ & 0.17 & - \\
Twigs & 254 & $0.30 \mathrm{~g}+0.10$ & 0.13 & 22.0 \\
& & $(1.5 \mathrm{~mm})$ & $(1.3 \mathrm{~mm})$ & $(4.3 \mathrm{~mm})$ \\
\hline
\end{tabular}




\section{RESULTS}

Using Eqs. (1a), (2a), (3a, b), and (4a, b) for summer and (1b), (2b), (3c), and (4c) for winter, the optimal diets for snowshoe hare (av. wt $=1.35 \mathrm{~kg}$ in summer and $1.5 \mathrm{~kg}$ in winter: Rowan and Keith, 1959) were computed using linear programming with a goal of either energy maximization or time minimization. Diets were computed for an average individual in the population because the observed diets could not be separated to sexes, reproductive states, size, etc., given that diets were determined by counting consumed leaves, twigs, etc., found in the environment. For summer, the average optimal diet was computed as the weighted average of the optimal diets for reproductive females and males/nonreproductive females. Reproductive females, according to Bookhout's (1965) study of a snowshoe hare population in the Upper Peninsula of Michigan, comprise $26 \%$ of the population when the population is increasing. Table IX contains a comparison of the predicted and observed diet values. To compute the winter diet, the $\mathrm{Na}^{+}$constraint had to be deleted, since the hare are not quite able in the model to attain $\mathrm{Na}^{+}$requirements $\left(3 \times 10^{-4} \mathrm{~g}\right.$ short fall/day). This may explain why hare consume the bark of trees since bark is relatively high in $\mathrm{Na}^{+}(80 \mathrm{ppm}$ : Likens and Bormann, 1970). There was no way to include bark consumption in the model because although known to occur at a low

TABLE IX

Comparisons of Diets Predicted by the Linear Program Model and Observed Diets for Summer and Winter, Indicating That Hare Appear to Forage as Energy Maximizers

\begin{tabular}{|c|c|c|c|c|c|c|}
\hline & \multicolumn{2}{|c|}{$\begin{array}{c}\text { Time } \\
\text { minimized }\end{array}$} & \multicolumn{2}{|c|}{$\begin{array}{c}\text { Energy } \\
\text { maximized }\end{array}$} & \multicolumn{2}{|c|}{ Observed } \\
\hline & $\mathrm{g}$ & $\%$ & $\mathrm{~g}$ & $\%$ & $\mathrm{~g}$ & $\%$ \\
\hline \multicolumn{7}{|l|}{$\overline{\text { Summer }}$} \\
\hline Leaves & 154.2 & 89.2 & 34.8 & 14.5 & 25.6 & 10.6 \\
\hline Herbs & 6.8 & 3.9 & 194.1 & 80.9 & 212.9 & 88.3 \\
\hline Fungus & 12.0 & 6.9 & 11.1 & 4.6 & 2.7 & 1.1 \\
\hline Total & 173.0 & & 240.0 & & $241.2 \pm 50.8$ & $(n=13)$ \\
\hline Time (min/day) & 67.4 & & 126.4 & & $131.0 \pm 31.2$ & $(n=8)$ \\
\hline Energy (kcal/day) & 318.4 & & 558.7 & & 571.0 & \\
\hline \multicolumn{7}{|l|}{ Winter } \\
\hline Deciduous & 0 & 0. & 190.5 & 75.1 & - & 78.9 \\
\hline Coniferous & 212.8 & 100.0 & 63.0 & 24.9 & - & 21.1 \\
\hline Total & 212.8 & & 253.5 & & & \\
\hline Time $(\min /$ day $)$ & 170.2 & & 202.8 & & 202.8 & \\
\hline Energy (kcal/day) & 312.8 & & 357.4 & & - & \\
\hline
\end{tabular}


level, hare were never observed consuming bark during cropping rate measurements. Finally, bark does not appear to serve as a summer $\mathrm{Na}^{+}$ source, since fungus provides more $\mathrm{Na}^{+}$per unit of digestive capacity filled than does bark.

A $X^{2}$ contingency table can be used to compare predicted and observed diets, but as the number of observations (items observed to be eaten) increases, even the smallest percentage difference between the model and the observed diet will lead to statistically significant differences, since the $X^{2}$ value is directly proportional to sample size. This problem is especially apparent in this case because of the small number of degrees of freedom (small number of table cells). A modification of a $X^{2}$ test to account for increasing sample size employs Pearson's contingency coefficient which scales $X^{2}$ values by the number of observations to arrive at an indication of degree of association $[0$ is the highest positive association, 0.5 is a random association and 1 is the most negative association (Conover, 1971)].

A $X^{2}$ analysis based upon numbers of items eaten indicates that the predicted time-minimized diet in both summer and winter is very different from the observed diet (summer: $X^{2}=757.0, \quad p<0.001$; winter: $X^{2}=1299.4, p<0.001$ ) and their Pearson contingency coefficients approach random association (summer: $R_{1}=0.57$; winter: $R_{1}=0.58$ ). For the predicted energy-maximized diets, mixed results are achieved. The summer and winter diets are significantly different from observed (summer: $X^{2}=17.8, p<0.01$; winter: $X^{2}=4.7, p<0.03$ ); however, the Pearson contingency coefficients indicate high association between predicted and obscrved diets (summer: $R_{1}=0.12$; winter: $R_{1}=0.04$ ). These observations are further substantiated by comparing the predicted daily food intake and feeding time for time minimizers and energy maximizers in summer with the measured daily intake and feeding time. The predicted energy-maximized intake and feeding time are not different from observed $(t=0.02, p<0.90$, and $t=0.14, p<0.85$ ), but a time minimizers' intake and feeding time approach a significant difference from the observed values $(t=1.29$, $p<0.25$, and $t=1.92, p<0.08)$. Correlation coefficients between predicted and observed diets indicate close agreement for an energy-maximizing strategy $\left(r^{2}=0.99, p<0.001, n=5\right)$ and little agreement with a timeminimizing strategy $\left(r^{2}=0.32\right.$, n.s., $\left.n=5\right)$. Even though precise determination of the time-minimized diet is impossible, given the difficulty in obtaining energy requirement values, we can reject the possibility that they are time-minimizers because the deviation from observed is so large. Furthermore, snowshoc harc appcar to forage rather closely to an energymaximizing strategy.

If we compare the predicted feeding time and habitat choices from the thermal physiology-dynamic-programming model (see above and Appendix) with the observed behavior, we find very close agreement. First, the predicted 


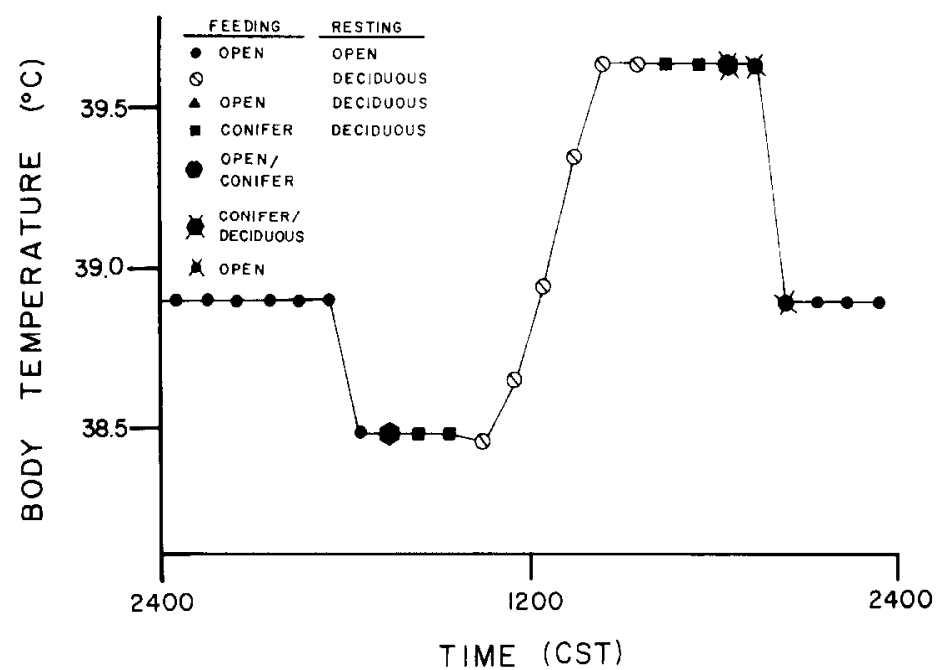

FIG. 2. Predicted activity and habitat choice for a snowshoe hare based upon its thermal physiology for each hour of a summer day.

and observed total activity times are not significantly different (Fig. 1: 8.7 vs $8.4 \pm 2.0, n=8, t=0.14, p<0.90)$. Second, the predicted and observed activity peaks correspond (Fig. 1: peaks predicted at 0600-1000 and $1700-2200$, and $85 \%$ of observed activity occurs at these times). Finally, the predicted fraction of each hour spent feeding is correlated with the observed hourly fraction $\left(r^{2}=0.78, n=24, p<0.001\right)$.

The thermal model's predictions for a hare's hourly behavior-habitat choices are presented in Fig. 2. Hare are predicted to spend $53 \%$ of the day in areas of open forest, primarily at night, and $47 \%$ of the day in dense forest ( $76 \%$ of this in conifer thickets). From the observation of penned hare, 74 animal hours were spent in the open (outside the nest box) generally at night, and 70 were spent inside the nest box. These observations were not significantly different from the predicted habitat use $\left(X^{2}=0.15, p<0.75\right)$. Furthermore, the model predicts that $72.4 \%$ of hare summer feeding should be in deciduous or open habitats. Of 812 food items consumed by hare, $74.5 \%$ were in deciduous areas $\left(X^{2}=1.80, p<0.40\right.$, with a strong coefficient of association, 0.05).

Belovsky (1981a) points out that herbivores should select food items if they are greater than some minimum digestibility and size for each food class (leaves, twigs, etc.). These minimum values are based upon simultaneous search for food items and minimum food characteristics necessary for survival. The minimum digestibility $(D$ : fraction) and size ( $I$ : $\mathrm{g} /$ item) values can be defined as (Belovsky, 1981a)

$$
D \geqslant M B / V R_{\mathrm{f}} K
$$


and

$$
I \geqslant M / T_{\mathrm{f}} K C_{r} D,
$$

where $M$ is metabolism ( $\mathrm{kcal} /$ day), $B$ is food bulk (wet wt/dry wt), $V$ is digestive organ capacity (wet wt), $R_{\mathrm{f}}$ is the flow rate of food through the digestive organ (number of times the organ empties each day), $K$ is food energy content $(\mathrm{kcal} / \mathrm{g}$ dry $\mathrm{wt}), T_{\mathrm{f}}$ is maximum feeding time (min/day), and $C_{r}$ is cropping rate (items $/ \mathrm{min}$ ).

Because plant quality is measured as mineral plus protein content, rather than digestibility, a conversion is required for comparison. Belovsky (1981a) demonstrates that the digestibility of plants for moose is correlated with mineral plus protein content. The same is observed for hare digestibilities of leaves, herbs, and twigs (Figs. $3 a$ and $3 b$ ). This correlation may be due to

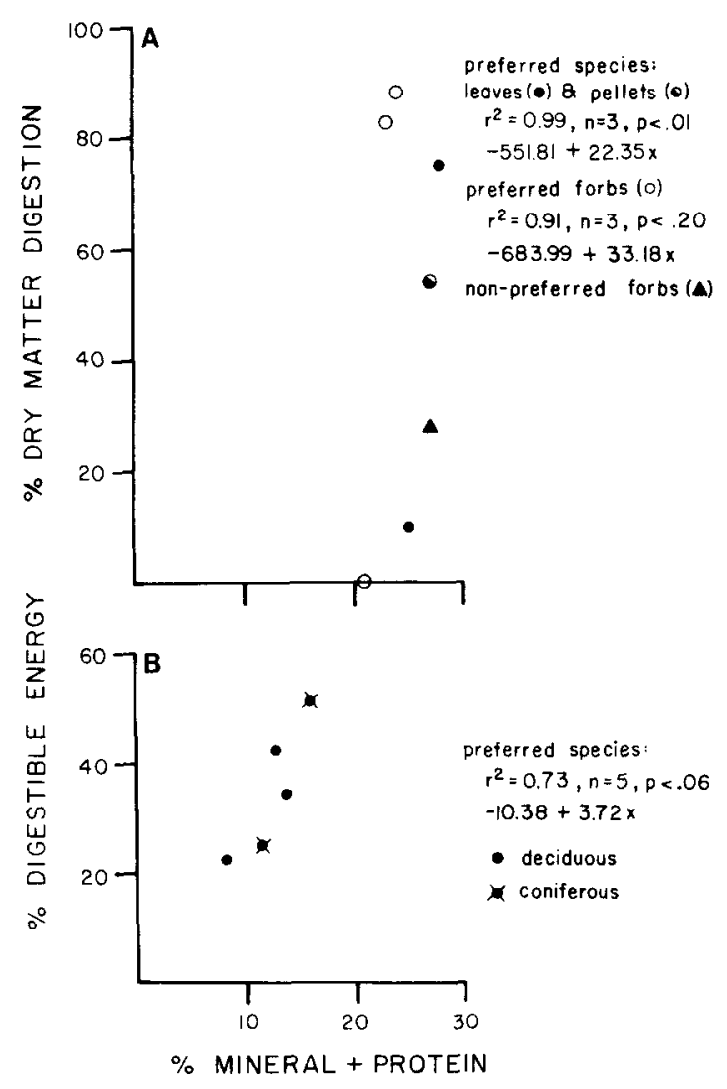

FIG. 3. (A) Dry matter digestibility of summer plants (highly soluble foods) by snowshoe hare plotted against the food's mineral plus protein content. (B) Dry matter digestibility of winter twigs by snowshoe hare (Mautz et al., 1976; Walski and Mautz, 1977) plotted against twig mineral plus protein content. Regressions for these values are presented. 
soluble nutrients stimulating symbiotic microorganisms in the gut which accelerates the breakdown of plant tissues (Belovsky, 1981a). If we use the average values for the parameters during summer and winter in Eqs. (5) and (6), $D$ and $I$ can be computed (Table X).

To determine whether hare select food items on the basis of $D$ and $I$, two analyses can be made: (1) compare observed $D$ and $I$ values with those predicted, and (2) compare the species composition of the diet observed with that predicted using $D$ and $I$. For $I$, the predicted and observed values are very close $\left(r^{2}=0.95, n=4, p<0.05\right)$. Belovsky (1981a) arrived at observed measures of $D$ for Isle Royale moose using the proportion of plants observed to be fed upon by moose within cach specics; this could not be done for hare because their feeding choices are restricted and masked by the intensity of moose feeding at Isle Royale.

Using the predicted $D$ (converted to mineral plus protein: Fig. 3 ) and $I$ values, the species composition of hare diets within a plant class (leaves, twigs, forbs, etc.) can be predicted (Belovsky, 1981a). The proportional composition of a hare's diet $\left(d_{i}\right)$ within a food class is defined as

$$
d_{i}=q_{i} s_{i} a_{i} / \frac{\searrow}{i} q_{i} s_{i} a_{i},
$$

where $q_{i}$ is the probability that a plant of species $i$ will have a mineral plus protein content greater than $D, s_{i}$ is the probability that a plant of species $i$

TABLE $\mathrm{X}$

. Comparison of Predicted and Observed Food Characteristics, Based upon Minimum Quality and Item Size Selected by Snowshoe Hare

\begin{tabular}{lcc}
\hline & Predicted & Observed \\
\hline$D(\%$ mineral + protein $)$ & & \\
$\quad$ Summer & 25.9 & - \\
$\quad$ Leaves & 21.4 & - \\
$\quad$ Forbs & 10.3 & - \\
Winter & 12.2 & \\
$\quad$ Deciduous twigs & & \\
$\quad$ Coniferous twigs & & 0.09 \\
& & 0.17 \\
(g/item) & 0.08 & \\
Summer & 0.22 & 0.15 \\
$\quad$ Leaves & & 0.13 \\
$\quad$ Forbs & 0.16 & \\
$\quad$ Winter & 0.13 & \\
$\quad$ Deciduous twigs & & \\
$\quad$ Coniferous twigs &
\end{tabular}




\section{TABLE XI}

Proportion of Plants of Each Species That Are of Sufficient Digestibility $(D)$ and Item Size (I) for Summer and Winter ${ }^{a}$

\begin{tabular}{|c|c|c|c|c|c|}
\hline & \multicolumn{2}{|c|}{ Fraction } & \multirow{2}{*}{$\begin{array}{c}\text { Relative } \\
\text { abundance }\end{array}$} & \multicolumn{2}{|c|}{ Diet } \\
\hline & $>D$ & $>I$ & & $P$ & $O$ \\
\hline \multicolumn{6}{|l|}{ Summer } \\
\hline \multicolumn{6}{|l|}{ Leaves } \\
\hline Sorbus americana & 0.73 & 0.87 & 0.53 & 61.9 & 68.9 \\
\hline Alnus rugosa & 0.53 & 0.93 & 0.23 & 20.9 & 21.6 \\
\hline Rubus ideus & 0.49 & 0.66 & 0.06 & 3.6 & 1.4 \\
\hline Betula papyrifera & 0.50 & 0.07 & 0.02 & 0.1 & 0 \\
\hline Acer spicatum & 0.59 & 0.77 & 0.07 & 5.9 & 2.7 \\
\hline Betula alleghaniensis & 0.89 & 0.58 & 0.02 & 1.9 & 1.4 \\
\hline Cornus stolonifera & 0.89 & 0.93 & 0.03 & 4.6 & 2.7 \\
\hline Lonicera canadensis & 0.04 & 0.16 & 0.01 & $t r$ & 0 \\
\hline Diervilla lonicera & 0.33 & 0.84 & 0.01 & 0.5 & 0 \\
\hline \multirow[t]{2}{*}{ Rubus parviflorus } & 0.37 & 0.99 & 0.01 & 0.7 & 1.4 \\
\hline & & & & \multicolumn{2}{|c|}{$\begin{array}{c}r^{2}=0.99, p<0.001 \\
96 \% \text { of diet }\end{array}$} \\
\hline \multicolumn{6}{|l|}{ Forbs } \\
\hline Streptipus roscus & 0.97 & 0.99 & 0.07 & 25.1 & 32.8 \\
\hline Dryopteris spinulosa & 0.79 & 0.99 & 0.13 & 38.0 & 29.8 \\
\hline Aralia nudicaulis & 0.42 & 0.99 & 0.08 & 12.5 & 14.9 \\
\hline Lycopodium sp. & 0 & 0.99 & 0.66 & 0 & 0 \\
\hline \multirow[t]{2}{*}{ Clintonia borealis } & 0.94 & 0.99 & 0.07 & 24.4 & 22.5 \\
\hline & & & & \multicolumn{2}{|c|}{$\begin{array}{c}r^{2}=0.84, p<0.05 \\
56 \% \text { of diet }\end{array}$} \\
\hline \multicolumn{6}{|l|}{ Winter } \\
\hline \multicolumn{6}{|l|}{ Deciduous twigs } \\
\hline Sorbus americana & 0.081 & 0.14 & 0.31 & 34.2 & 16.6 \\
\hline Betula alleghaniensis & 0.274 & 0.46 & 0.045 & 55.2 & 55.0 \\
\hline Betula papyrifera & 0.001 & 0.65 & 0.142 & 0.9 & 10.4 \\
\hline Acer spicatum & 0.003 & 0.46 & 0.49 & 6.6 & 16.0 \\
\hline Corylus cornuta & 0.036 & 0.94 & 0.004 & 1.4 & 0.3 \\
\hline Amelanchier sp. & 0.050 & 0.92 & 0.004 & 1.7 & 0.7 \\
\hline \multicolumn{6}{|l|}{ Coniferous twigs } \\
\hline Abies balsamea & 0.083 & 0.87 & 0.43 & 20.7 & 10.6 \\
\hline \multirow[t]{2}{*}{ Thuja occidentalis } & 0.802 & 0.26 & 0.57 & 79.3 & 89.4 \\
\hline & & & & \multicolumn{2}{|c|}{$\begin{array}{c}r^{2}=0.90, p<0.001 \\
65 \% \text { of diet }\end{array}$} \\
\hline
\end{tabular}

a These values and the relative species abundance are used to predict the species composition of summer and winter diets, which are compared with the observed dicts. 
will have an item size greater than $I$ or less than some observed maximum, and $a_{i}$ is the probability of encountering a plant of species $i$ (frequency of occurrence) (Belovsky, 1981a). Using the predicted $D$ and $I$ values, and the observed mean mineral plus protein and item size values with their standard deviations for each plant species in a standard normal model (Belovsky 1981a), the probability that a plant of species $i$ will satisfy a hare's $D$ and $I$ requirements $\left(q_{i}\right.$ and $\left.s_{i}\right)$ can be computed. Table XI contains the predicted and observed species compositions of hare diets, indicating very close agreement (mean $r^{2}=0.90$ ).

\section{Discussion}

All of the above results indicate that hare may forage in an energymaximizing manner and follow the models developed for Isle Royale moose (Belovsky, 1978, 1981a, b). This indicates that a linear-programming model for an energy-maximizing diet appears to be a good predictor of composition of the diet by food classes (leaves, twigs, etc.), while the joint probability of acceptable plant characteristics determines the species composition of each diet food class. Two models are required since the diet composition by food class is a decision process involving nonsimultaneous search for food; i.e., feeding on one class precludes feeding on others because of their being in different microhabitats, while the species composition of each class is a decision process based upon simultaneous search within a microhabitat. This may represent a general pattern and set of models for herbivore foraging (Belovsky, 1978, $1984 \mathrm{a}, \mathrm{b}$ ).

Two additional aspects of hare biology can be assessed using the foraging models. First, one can ascertain whether body size and life history parameters can be predicted from foraging considerations. Second, the foraging model can be examined for sensitivity to parameter changes which may shed light upon which foraging ecology parameters might produce demographic variations.

All of the foraging constraint equations were written as functions of weight, sex, and reproductive status. These equations can be used to determine at what body sizes a hare's life history parameters (reproduction, body growth, weaning, etc.) can be energetically sustained.

Figure 4a presents the energy-maximized intake versus energy requirements for males and nonreproductive females of different weights in summer, while Fig. $4 \mathrm{~b}$ portrays the relationship for reproductive females in summer. Summer is the period of greatest food availability so that activities of high nutritional demand (growth, reproduction, etc.) must occur at this time if they take place at all. This analysis points out that hare can forage on their own without any nutritional supplement at a weight of approximately 

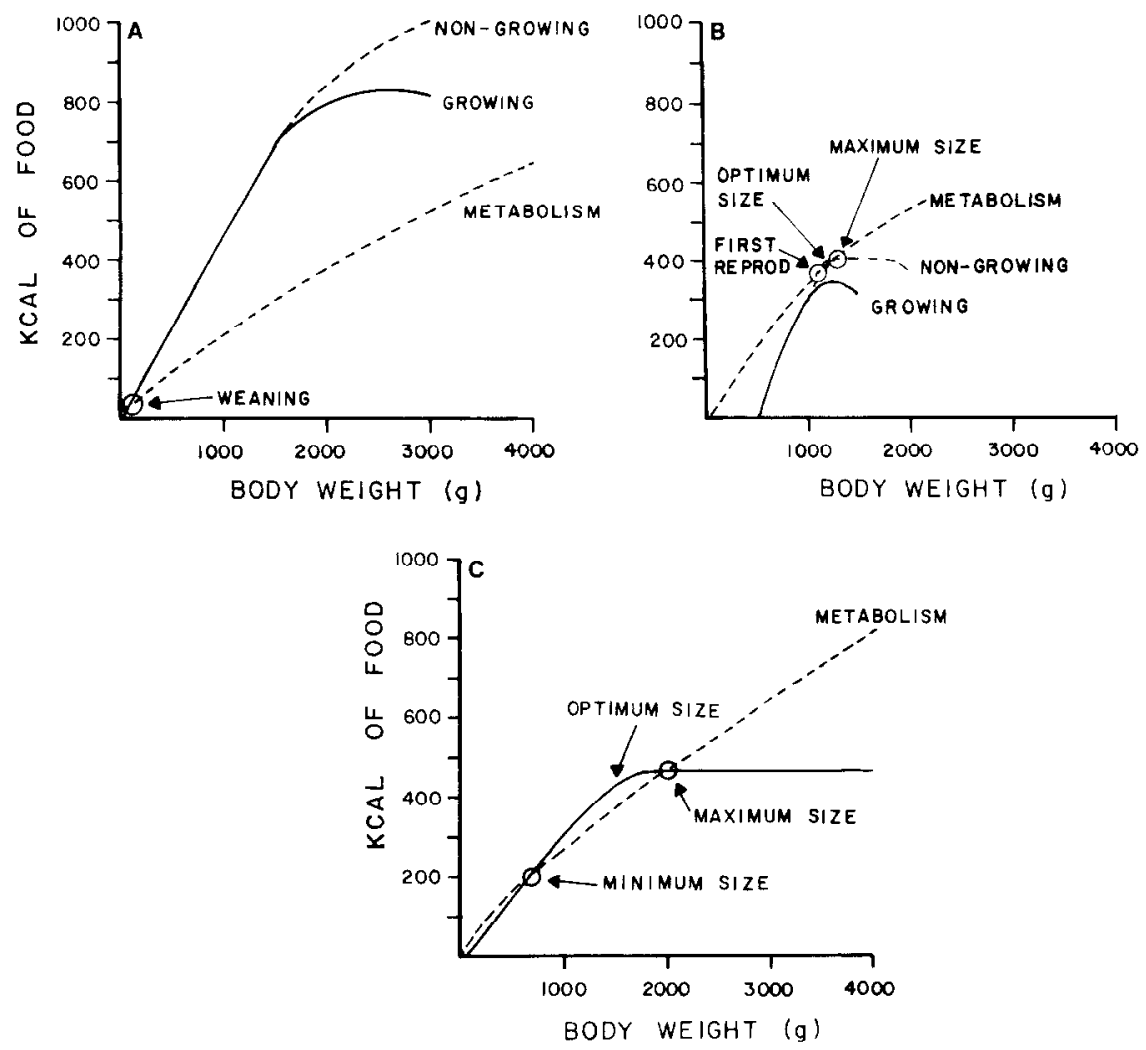

FIG. 4. Gross energy intake (-) predicted from the optimal diet model plotted for snowshoe hare of different body sizes (g), along with their metabolism (--): (A) males and nonreproductive females in summer, (B) reproductive females in summer, and (C) adults of either sex in winter. In the appropriate figures, important life history stages are denoted (weaning, age at first reproduction, maximum and minimum sizes), as well as the optimum size for feeding.

$100 \mathrm{~g}$ (Fig. 4a: growth vs metabolism), which is a weaning age of 17 days after birth given the observed growth rate [weight in grams = $65 e^{0.025 \text { (days since birth) }}, r^{2}=0.90, n=60$ (weight every 2 days) for two young in captivity provided with natural foods]. Grange (1932) claims that young hare start feeding on vegetation at 8 days of age, and in a short time thereafter are weaned; while Aldous (1937) and Severaid (1945) claim that hare are completely independent by 30 days.

Figure $4 \mathrm{~b}$ indicates that a hare cannot reproduce and still maintain body growth and, foregoing growth, a female must be at least $1000 \mathrm{~g}$ to produce a litter. Grange (1932) found that females were sexually active within 5 months of birth, and with his average growth rate of $9 \mathrm{~g} / \mathrm{day}$, they would then weigh $1350 \mathrm{~g}$. Aldous (1937) claims that females are not sexually active 
in their first year, which would be the case at Isle Royale, as they could not reach $1000 \mathrm{~g}$ by the onset of winter.

Figure $4 \mathrm{a}$ indicates that male hare should have an optimum feeding size of $3500 \mathrm{~g}$ and a maximum of $8200 \mathrm{~g}$ if summer is the season determining this value. These body size values are much larger than those observed (Rowan and Keith, 1959). Winter (Fig. 4c), however, may determine optimum and maximum sizes because it is during winter when food is in short supply that hare may have to be at the best size to forage in order to survive. For males and females, the predicted winter optimum and maximum sizes are 1500 and $2000 \mathrm{~g}$, respectively. Observed male sizes are approached (November average is $1500 \mathrm{~g}$, November average $+95 \%$ confidence maximum is $1600 \mathrm{~g}$ : Rowan and Keith, 1959). For females, the foraging model in summer (Fig. 4b) sets an optimum size at $1250 \mathrm{~g}$ and a maximum at $1350 \mathrm{~g}$, lower than that set for males or females in winter (Fig. 4c). Rowan and Keith (1959), however, indicate that females attain an average weight of $1554 \mathrm{~g}$ and a maximum (upper $95 \%$ confidence) of $1636 \mathrm{~g}$ in November. These values are larger than those indicated by the summer model, and the discrepancy probably arises from an overestimate of the $\mathrm{Na}^{+}$demand for reproduction. Nevertheless, the model indicates that females should have less body size variation than males because of their stricter energy and $\mathrm{Na}^{+}$ constraints, which is observed (Rowan and Keith, 1959; Keith and Windberg, 1978). Finally, these data indicate that hare body sizes for weaning, first reproduction, and male and female adult sizes approach those predicted by the foraging model.

A serrsitivity analysis of the model can be used to assess how changes in model constraint and parameter values lead to variations in diet predictions. By increasing or decreasing each constraint value by $10 \%$, it is found that the greatest diet variation is from changes in the feeding time constraint, producing a $35 \%$ change in summer herb and forb intake, and a $75 \%$ change in winter twig intake. Since parameter changes are proportional to constraint changes, cropping rates should be the most sensitive parameter values for the model. A $10 \%$ variation in foraging time or cropping rates is within the $35 \%$ confidence interval for these values; however, variation in these values arising from feeding sites and daily thermal variability makes it unlikely that the observed average values would vary by as much as $10 \%$ due to measurement error.

Sensitivity analysis also can be used to determine which parameter or constraint values are most likely capable of leading to changes in survival or natality. Using the linear-programming model for body weight and sex variation, we can determine the smallest percent variation in each foraging constraint or parameter necessary to prevent hare reproduction (failure to satisfy fentale reproductive nutritional demands), juvenile survival (failure to satisfy nutritional demands for juvenile growth), or adult survival (failure to 
satisfy nutritional demands for adult weight maintenance). Juvenile growth and adult weight maintenance are necessary for hare survival (Keith and Windberg, 1978). All solutions to models for adults were carried out at the predicted optimal body sizes set by foraging (winter for male hare and summer for females: see above). Finally, as pointed out above, the feeding time constraint is most sensitive to variation; however, for a hare to have environmentally induced variation in feeding time, climate would have to modify the thermal physiology model. This can be discounted as important in hare demography since their demographic changes are known to be independent of weather fluctuations (Meslow and Keith, 1971; Keith and Windberg, 1978; Finerty, 1980), indicating that climate may not vary enough between years to affect average feeding time dramatically.

Table XII contains a list of the percentage fluctuations in model parameters necessary for the failure to reproduce or survive. The most sensitive demographic response is reproduction, followed by winter survival and then juvenile growth. Indeed, hare populations appear to have the greatest variation in reproduction followed by winter survival (Keith and Windberg, 1978; Cary and Keith, 1979).

Reproductive failure is most sensitive to variation in $\mathrm{Na}^{+}$intake which would arise from changes in fungus $\mathrm{Na}^{+}$content and/or abundance $(\sim 1.0 \%$ variation). Changes in digestibility and abundance for leaves and herbs are next in importance for reproductive success $(\sim 1.1$ and $1.5 \%)$; nevertheless, the difference between the impact of fungus and leaf-herb quality-abundance variations are very similar, essentially inseparable. $\mathrm{Na}^{+}$availability may

\section{TABLE XII}

Necessary Changes in Foraging Parameters Needed to Lead to Changes in Reproduction and Mortality That Could Account for Population Cyclicity

\begin{tabular}{|c|c|c|c|}
\hline & \multicolumn{3}{|c|}{$\%$ Change required for failure } \\
\hline & $\begin{array}{c}\text { To } \\
\text { reproducc }\end{array}$ & $\begin{array}{l}\text { For juvenile } \\
\text { growth }\end{array}$ & $\begin{array}{l}\text { For adult } \\
\text { maintenanec }\end{array}$ \\
\hline \multicolumn{4}{|l|}{ Food abundance } \\
\hline Fungus & -1.0 & -88 & -100 \\
\hline Leaves and herbs & -1.5 & -72 & -52 \\
\hline Twigs & - & - & -19 \\
\hline \multicolumn{4}{|l|}{ Food quality } \\
\hline $\mathrm{Na}^{+}$in fungus & $->1.0$ & -93 & -100 \\
\hline $\begin{array}{l}\text { Digestibility of } \\
\text { leaves and forbs }\end{array}$ & -1.1 & -40 & -50 \\
\hline Digestibility of twigs & - & - & -12 \\
\hline
\end{tabular}


vary due to decomposition lag times in boreal forests (Hutchinson and Deevey, 1949; Kimmins, 1970; Finerty, 1980) and evidence exists that moose at the Isle Royale study site may have fluctuating numbers because of changes in $\mathrm{Na}^{+}$availability (Belovsky, 1981c). Also, there exists evidence that leaf-herb food quantity may vary by up to $28 \%$ between years, also a potential source for demographic changes. These food quantity or quality variations might arise from endogenous environmental variations and/or changes in consumer densities and represent a possible explanation for demographic changes.

Both juvenile and adult survival is most sensitive in the model to the digestibility of twigs, followed closely by twig abundance. The needed changes in leaf-herb-fungus quality-quantity $(40-100 \%$ predicted) to lead to a failure in adult weight maintenance or juvenile growth are greater than observed ( $28 \%$ observed) and, consequently, can be discounted. Twig abundance or quality might easily vary by the necessary amount, because twig availability is related to leaf production and the $28 \%$ observed change in leaf abundance could account for a $40 \%$ change in twig availability (Belovsky, 1984a), a value greater than the magnitude needed to change survival.

The results from the sensitivity analysis agree in part with an hypothesis and evidence explaining hare demographic changes (Keith, 1974; Keith and Windberg, 1978; Pease et al., 1979; Vaughn and Keith, 1981). These studies suggest that the abundance of twigs of sufficient quality for hare in winter sets winter survival and spring-summer reproduction through weight loss. Pease et al. (1979) have demonstrated experimentally that the survival of captive hare depends on the abundance of twigs of high nutritional quality. Such changes in food quality-abundance might arise from either endogenous environmental variation or through increasing twig consumption with increases in hare density or plant responses to browsing (Bryant, 1981). These results suggest that hare demographic studies should compare survival and reproduction not only with the dynamics of winter food characteristics but also with summer variations.

\section{Conclusions}

Snowshoe hare appear to forage in a manner consistent with a goal of energy maximization. The model employs a set of nested models to determine when and for how long a hare should feed, how feeding time should be allocated to different food types which are distributed in different microhabitats, and which food species should be consumed within each microhabitat. The same system of models has been employed for a series of herbivores (Belovsky, 1978, $1984 \mathrm{a}, \mathrm{b}$ ) suggesting that this model form may be of general application for generalist herbivores. Finally, the models 
appear to be applicable to answer questions dealing with life history parameters and the sensitivity of populations to demographic changes arising from foraging considerations.

\section{APPENDIX: Snowshoe Hare Thermal Balance}

The thermal balance for a snowshoe hare can be computed using the thermodynamic model developed by Porter and Gates (1969):

$$
\Delta H=M+Q_{\mathrm{abs}}-\gamma \varepsilon T_{r}^{4}-h_{\mathrm{c}}\left(T_{r}-T_{\mathrm{a}}\right)-E_{\mathrm{ex}}-E_{\mathrm{sw}} \pm C,
$$

where $\Delta H$ is heat gained or lost $\left(\mathrm{W} \mathrm{m}^{-2}\right), M$ is metabolic heat produced $\left(\mathrm{W} \mathrm{m}^{-2}\right), Q_{\mathrm{abs}}$ is solar radiation absorbed $\left(\mathrm{W} \mathrm{m}^{-2}\right), \gamma$ is the StefanBoltzmann constant $\left(\mathrm{W} \mathrm{m}^{-2} /{ }^{\circ} \mathrm{K}^{4}\right), \varepsilon$ is the emissivity of the animal's surface, $T_{r}$ is the animal's surface (fur) temperature $\left({ }^{\circ} \mathrm{K}\right), h_{\mathrm{c}}$ is the convection coefficient $\left(\mathrm{W} \mathrm{m}^{-2} /{ }^{\circ} \mathrm{K}\right), T_{\mathrm{a}}$ is ambient air temperature $\left({ }^{\circ} \mathrm{K}\right), E_{\text {ex }}$ is heat lost by respiratory evaporation $\left(\mathrm{W} \mathrm{m}^{-2}\right), E_{\mathrm{sw}}$ is heat loss by sweating, and $C$ is conductive heat loss $\left(\mathrm{W} \mathrm{m}^{-2}\right)$. $Q_{\mathrm{abs}}$ can be written as (Porter and Gates, 1969)

$$
Q_{\mathrm{abs}}=a z S+0.5\left[a s+\operatorname{ar}(S+s)+\varepsilon \gamma\left(T_{\mathrm{a}}^{4}+T_{v-\mathrm{g}}^{4}\right)\right],
$$

where $a$ is fur solar absorptivity, $z$ is the fraction of surface area exposed to solar radiation, $S$ is direct solar radiation $\left(\mathrm{W} \mathrm{m}^{-2}\right), s$ is indirect solar radiation $\left(\mathrm{W} \mathrm{m}^{-2}\right), r$ is the fraction of solar radiation reflected by the ground, and $T_{\mathrm{v}-\mathrm{g}}$ is the surface temperature of the vegetation and ground ( $\left.{ }^{\circ} \mathrm{K}\right) . C$ can be written as (Porter and Gates, 1969)

$$
C=f k\left(T_{r}-T_{\mathrm{v}-\mathrm{g}}\right) / d,
$$

where $f$ is the fraction of area conducting, $k$ is the conduction coefficient $\left({ }^{\circ} \mathrm{K} / \mathrm{cm}\right)^{-1}$, and $d$ is the distance between the hare and the ground. In addition to the above value for $C, \mathrm{I}$ included the energy required to warm food to body temperature after ingestion which can be a relatively high heat flux for a small animal.

The thermal environment data for Isle Royale was presented by Belovsky (1981b) and is summarized in Fig. A1. The thermal physiology parameters for hare were determined using captive individuals (see text). The hare surface temperature $\left(T_{r}\right)$ was found by placing a surface probe under the fur tips at 6 locations and averaging. This was done on constrained individuals. 


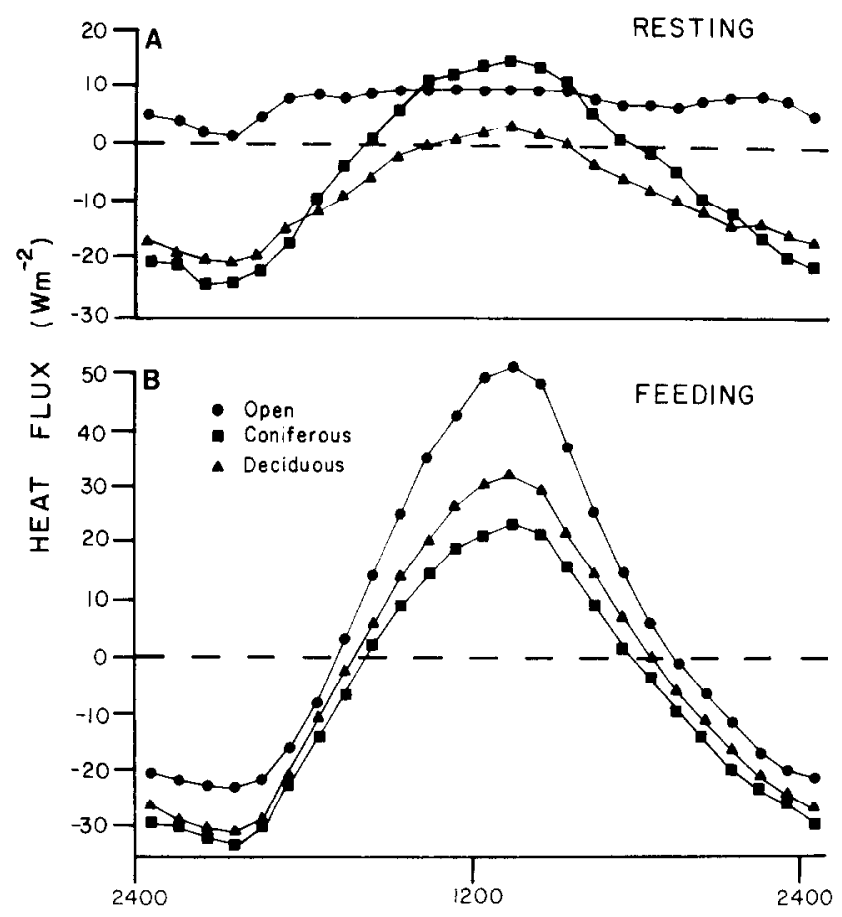

FIG. Al. A snowshoe hare's heat fluxes $\left(\mathrm{W} \mathrm{m}^{-2}\right)$ for resting (A) and active (B) are presented for each hour of an average summer day.

Although this is not an error-free measure since fur is a porous medium, the measure is no worse than that from a radiometer (Cena and Clark, 1973; W. Porter, pers. comm.). $T_{r}$ was correlated with $Q_{\text {a as }}$ to extrapolate to a variety of thermal environments.

Evaporative heat loss from respiration (sweating was assumed to be negligible) was measured by counting the breaths/minute for captive hare and multiplying by the hare's tidal volume based upon Schmidt-Nielsen's (1975) body mass-tidal volume relationship and assuming a body temperature of $38.6^{\circ} \mathrm{C}$. Measures of evaporative loss were related to $Q_{\mathrm{abs}}$ to extrapolate to other thermal environments.

The surface area of snowshoe hare was determined by dividing the body into a series of rcgular volumes (cylinders, spheres, etc.) and computing their surface areas based on linear dimensions (length, width, circumference). The computed surface areas were then correlated with body mass.

Thermal physiology parameters are summarized in Table AI. The computed $\Delta H$ values are presented in Fig. Al. 


\section{TABLE AI}

Thermal Parameters Necessary to Compute a Snowshoe Hare's Summer Thermal Budget

\section{Convection}

$h_{\mathrm{c}}=15.5 v^{0.6} \mathrm{~W} \mathrm{~m}^{-2} /{ }^{\circ} \mathrm{C}$

(Mitchell, 1976)

Open-deciduous-conifer feeding, $v=0.1$

Open-resting, $v=0.01^{a}$

Fraction of area exposed to convection

Feeding, 1.0

Resting, 0.8

Surface temperature

$$
T_{r}=\left[124.2+38.1 Q_{\mathrm{abs}}^{0.25}\right]^{\circ} \mathrm{K} \quad n=18, r^{2}=0.82^{b}
$$

Emissivity

$$
\varepsilon=0.98
$$

(Gates, 1980)

(summer Sylvilagus floridanus)

\section{Absorptivity}

$a=0.73$

(Gates, 1980)

(dorsal Sylvilagus floridanus)

Orientation $^{\mathrm{c}}$

Perpendicular to sun, $z=0.29$

Parallel to sun, $z=0.03$

Feeding, $z=0.16$

Surface area

$$
A=\left[34.4 W_{\mathrm{g}}^{0.55 \pm 0.24} \mathrm{~cm}^{2} \quad n-6, r^{2}=0.94\right.
$$

Metabolism

$$
\text { Resting, }\left(6.5 W^{0.75}\right) / 0.19=45.8 \mathrm{~W} \mathrm{~m}^{-2}
$$

Active, $\left(7.2 W^{0.75}\right) / 0.19=51.4 \mathrm{~W} \mathrm{~m}^{-2}$

Weight, $1.5 \mathrm{~kg}$

Evaporative cooling

$$
\begin{aligned}
& E_{\mathrm{ex}}=2.5 \times 10^{-3} e^{\left(4.6 Q_{\mathrm{abs}}^{0.25}-19.1\right)}(49 \mathrm{VP}) \\
& \mathrm{VP}=\text { vapor pressure }(\mathrm{mmHg})
\end{aligned}
$$

Conduction

$$
\begin{aligned}
& \text { Air: } k=2.5 \mathrm{~W} \mathrm{~m}^{-2}\left({ }^{\circ} \mathrm{K} / \mathrm{cm}\right)^{-1} \quad \text { (Schmidt-Nielsen, 1975) } \\
& d-0.5 \mathrm{~cm}
\end{aligned}
$$

\section{Proportion of area}

Feeding, 0

Resting, 0.2

Energy to warm ingested food

$$
=\left(311.75-T_{\mathrm{v}-\mathrm{g}}\right) \mathrm{W} \mathrm{m}^{-2} \times \frac{0.046 \mathrm{~g} / \mathrm{sec}}{1922 \mathrm{~m}^{2}} \times 0.52^{d} \times \frac{1}{2.388} \times 10^{-5} \mathrm{~W} \mathrm{~m}^{-2}
$$

${ }^{a} v$ Values scaled for height of snowshoe hare above the ground (Sellers, 1965) and different value for hare resting in the open because of heavy herbaceous cover in which they lie down.

${ }^{b} Q_{\text {abs }}$ computed for animal with a value of $z=0.16$.

c Based upon body dimensions $[D=16.4 \mathrm{~cm}, L=25.5 \mathrm{~cm}]$ (Montieth, 1973).

${ }^{d} 0.52$ represents the observed fraction of a day spent in foraging. 


\section{ACKNOWLEDGMENTS}

I thank T. W. Schoener, S. L. Lima, and J. B. Slade for critically reading early drafts of this paper and supplying helpful comments. I thank J. Cannon, K. Hay, D. Johnson, D. Pletcher, and J. B. Slade for their help in collecting the data, and the personnel of Isle Royale National Park for their help. The work was supported by NSF Grant DEB-78-02069 A01 to the author and T. W. Schoener, and grants to the author from the Environmental Education Fund, the Harvard Society of Fellows, and the Richmond Society, Harvard University.

\section{REFERENCES}

Aldous, C. M. 1937. Notes on the life history of the snowshoe hare, J. Mammal. 18, 46-57.

Austin, C. R., AND SHORT, R. V. 1972. "Embryonic and Fetal Development. Reproduction in Mammals, 2," Cambridge Univ. Press, London.

Belovsky, G. E. 1978. Diet optimization in a generalist herbivore: The moose, Theor. Pop. Biol. 14, 105-134.

Belovsky, G. E. 1981a. Food plant selection by a generalist herbivore: The moose, Ecology 62, 1020-1030.

Belovsky, G. E. 1981b. Optimal activity times and habitat choice of moose, Oecologia 48, $22-30$.

Belovsky, G. E. $1981 \mathrm{c}$. A possible population response of moose to sodium availability, $J$. Mammal. 62, 631-633.

Belovsky, G. E. 1984 a. Summer diet optimization by beaver, Amer. Midl. Natur., in press.

BelovsKy, G. E. 1984 b. Herbivore optimal foraging: A comparative test of three models, Amer. Natur., in press.

Belovsky, G. E., and Jordan, P. A, 1978. The time-energy budget of a moose, Theor. Pop. Biol. 14, 76-104.

Belovsky, G. E., AND Jordan, P. A. 1981. Sodium dynamics and adaptations of a moose population, J. Mammal. 62, 613-621.

BitTNer, S. L., AND RongSTAD, O. J. 1982. Snowshoe hares and allies (Lepus americanus and Alces), in "Wild Mammals of North America" (J. A. Chapman and G. A. Feldhammer, Eds.), pp. 124-145, John Hopkins Univ. Press, Baltimore.

Bоокноuт, T. A. 1965. "The Snowshoe Ilare in Upper Michigan: Its Biology and Feeding Coactions with White-Tailed Deer," Michigan Dept. Conserv. Res. Develop. Rep. No. 38.

Botkin, D. B., Jordan, P. A., Dominski, A. S., Lowendorf, H. S., and Hutchinson, G. E. 1973. Sodium dynamics in a northern ecosystem. Proc. Nat. Acad. Sci. USA 70, 2745-2748.

BRYANT, J. P. 1981. Phytochemical deterence of snowshoe hare browsing by adventitious shoots of four Alaskan trees, Science 213, 889-890.

CARY, J. R., AND KeITH, L. B. 1979. Reproductive change in the 10-year cycle of snowshoe hares, Canad. J. Zool. 57, 375-390.

CENA, K., AND Clark, J. A. 1973. Thermographic measurements of the surface temperatures of animals, J. Mammal. 54, 1003-1007.

Church, D. C., Smith, G. E., Fontenot, J. P., and Rallston, A. T. 1971. "Digestive Physiology and Nutrition of Ruminants," Oregon State Univ. Book Stores 2, 401-801.

Conover, W. J. 1971. "Practical Nonparametric Statistics," Wiley, New York.

Cook, C. W. 1972. "Energy Budget for Rabbits Compared to Cattle and Sheep," Colorado State Univ. Range Science Dept., Sci. Ser. N. 13. 
Finerty, J. P. 1980. "Fluctuations in Small Mammal Populations," Yale Univ. Press, New Haven, Conn.

GAIES, D. 1980. "Biophysical Ecology," Springer-Verlag, New York.

GRangE, B. 1932. Observations of the snowshoe hare, Lepus americanus phaenotus Allen. $J$. Mammal. 13, 1-19.

Hart, J. S., Poht, H., ann Tener, J. S. 1965. Seasonal acclimatization in varying hare (Lepus americanus), Canad. J. Zool. 43, 731-744.

Hemmingsen, A. M. 1960. Energy metabolism as related to body size and respiratory surfaces and its evolution, Rep. Steno. Mem. Hosp. Nord. Insulin Lab. 9, 3-110.

Holter, J. S., Tyler, G., AND Walski, T. 1974. Nutrition of the snowshoe hare (Lepus americanus), Canad. J. Zool. 52, 1553-1558.

Hutchinson, G. E., And Deevey, E. S. 1949. Ecological studies on populations, Surv. Biol. Progr. 1, 325-359.

Johnson, W. J. 1970. Food habits of the red fox in Isle Royale National Park, Lake Superior, Amer. Midl. Natur. 84, 568-572.

Jordan, P. A., Botkin, D. B., Dominski, A. S., Lowendorf, H. S., ANd Belovsky, G. E. 1973. The dilemma of sodium for moose of Isle Royale, 9th North. Amer. Moose Workshop.

KeITH, L. B. 1963. "Wildlife's Ten-year Cycle," Univ. of Wisconsin Press, Madison.

KeITH, L. B. 1974. Some features of population dynamics in mammals. Proc. Int. Congr. Game Biol. No. 11, 17-58.

KEITH, L. B., AND WINDBERG, L. A. 1978. A demographic analysis of the snowshoe hare cycle, Wildl. Monogr. No. 58.

Kimmins, J. P. 1970. Cyclic fluctuations in herbivore populations in northern ecosystems: a general hypothesis, Ph. D. Thesis, Yale University, New Haven, Conn.

Kleiber, M. 1961. "The Fire of Life," Wiley, New York.

LARChER, W. 1975. "Physiological Plant Ecology," Springer-Verlag, Berlin.

Likens, G. E., And Bormann, F. H. 1970. Chemical analyses of plant tissues from the Hubbard Brook ecosystem in New Hampshire, Yale School For. Bull. No. 79.

Mautz, W. W., Walski, T, W., and URban, W. E., JR., 1976. Digestibility of fresh frozen versus pelleted browse by snowshoe hares, J. Wildl. Mgmt. 40, 496-499.

MCBeE, R. H. 1971. Significance of intestinal microflora in herbivory, Ann. Rev. Ecol. Syst. 2, 165-176.

MEch, L. D. 1966. "The Wolves of Isle Royale," U. S. Nat. Park Fauna 7.

MECH, L. D., AND TESTER, J. R. 1965. Biological, behavioral and physical factors affecting home ranges of snowshoe hares (Lepus americanus), raccoon (Procyon lotor) and whitetailed deer (Odocoileus virginianus) under natural conditions, Prog. Rep. No. 1, Mus. Nat. Hist. Univ. Minn. Tech. Rep. No. 9.

MEsLow, E. C., AND KEITH, L. B. 1971. A correlation analysis of weather versus snowshoe hare population parameters, J. Wildl. Mgmt. 35, 1-15.

Mitchell, J. W. 1976. Heat transfer from spheres and other animal forms, Biophys. J. 16, 561-569.

Monteith, J. L. 1973. "Principles of Environmental Physics," American Elsevier, New York.

National Research Council. 1966. "Nutrition of the Domestic Rabbit."

Pease, J. L., Vowles, R. H., AND KeITH, L. B. 1979. Interaction of snowshoe hares and woody vegetation, J. Wildl. Mgmt. 43, 43-60.

Porter, W. P. AND Gates, D. M. 1969. Thermodynamic equilibria of animals with environment, Ecol. Monogr. 39, 227-244.

Pyke, G. H., Pulliam, H. R., and Charnov, E. L. 1977. Optimal foraging: A selective review of theory and tests. Quart. Rev. Biol. 55, 137-154.

Rowan, W., AND KeITH, L. B. 1959. Monthly weights of snowshoe hares from north-central Alberta, J. Mammal. 40, 221-223. 
Schmidt-NiElSEN, K. 1975. "Animal Physiology: Adaptation and Environment," Cambridge Univ. Press, London.

Schoener, T. W. 1971. Theory of feeding strategies, Ann. Rev. Ecol. Syst. 2, 369-403.

Scoggins, B. H., et al. 1970. Physiological and morphological responses of mammals to changes in their sodium status, Mem. Soc. Endocrinol. 18, 577-600.

Sellers, W. D. 1965. "Physical Climatology," Univ. of Chicago, Chicago.

SEveraid, J. H. 1945. Breeding potential and artificial propagation of the snowshoe hare, $J$. Wildl. Mgmt. 9, 290-295.

SMith, M. C., LeATHeRLAND, J. F., AND MYERs, K. 1978. Effects of seasonal availability of sodium and potassium on the adrenal cortical function of a wild population of snowshoe hares, Lepus americanus, Canad. J. Zool. 56, 1869-1876.

TAYLOR, C. R. 1973. Energy cost of animal locomotion, in "Comparative Physiology" (L. Bolis, K. Schmidt-Nielsen, and S. H. P. Maddrell, Eds.), pp. 23-42, North Holland, New York.

VAughN, M. R., AND KeITH, L. B. 1981. Demographic response of experimental snowshoe hare populations to overwinter food shortage, J. Wildl. Mgmt. 45, 354-380.

WaLskI, T. W., AND MAUTz, W. W. 1977. Nutritional evaluation of three winter browse species of snowshoe hares, J. Wildl. Mgmt. 41, 144-147. 